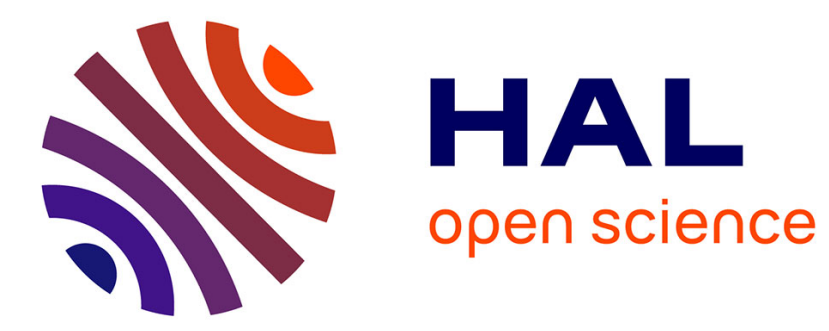

\title{
Free movement: A key for welfare improvement in sport horses?
}

Clémence Lesimple, Lola Reverchon-Billot, Patrick Galloux, Mathilde Stomp, Laetitia Boichot, Caroline Coste, Séverine Henry, Martine Hausberger

\section{- To cite this version:}

Clémence Lesimple, Lola Reverchon-Billot, Patrick Galloux, Mathilde Stomp, Laetitia Boichot, et al.. Free movement: A key for welfare improvement in sport horses?. Applied Animal Behaviour Science, 2020, 225, pp.104972. 10.1016/j.applanim.2020.104972 . hal-02496127

HAL Id: hal-02496127

https://hal-univ-rennes1.archives-ouvertes.fr/hal-02496127

Submitted on 31 Mar 2021

HAL is a multi-disciplinary open access archive for the deposit and dissemination of scientific research documents, whether they are published or not. The documents may come from teaching and research institutions in France or abroad, or from public or private research centers.
L'archive ouverte pluridisciplinaire HAL, est destinée au dépôt et à la diffusion de documents scientifiques de niveau recherche, publiés ou non, émanant des établissements d'enseignement et de recherche français ou étrangers, des laboratoires publics ou privés. 
Clémence Lesimple, Lola Reverchon-Billot, Patrick Galloux, Mathilde Stomp, Laetitia Boichot, et al.. Free movement: A key for welfare improvement in sport horses?. Applied Animal Behaviour Science, Elsevier, 2020, 225, pp.104972. 〈10.1016/j.applanim.2020.104972〉. 〈hal02496127>

\section{Authors' post-print}

Editor's version available at the following:

https://doi.org/10.1016/i.applanim.2020.104972

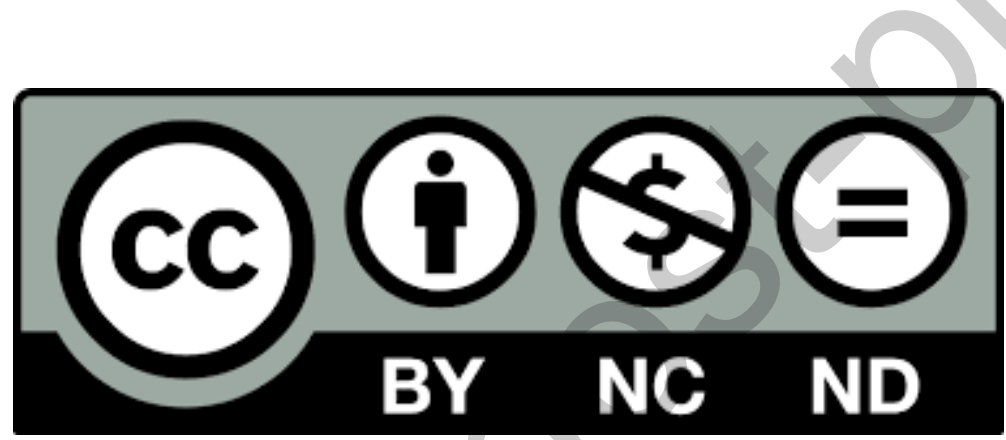




\section{$1 \quad$ Free movement: a key for welfare improvement in sport horses?}

2

3 Clémence Lesimple ${ }^{1 x^{*}}$, Lola Reverchon-Billot ${ }^{1 \times}$, Patrick Galloux ${ }^{2}$, Mathilde Stomp ${ }^{1}$, Laetitia
5

$6{ }^{x}$ Equal contribution

$7 \quad{ }^{1}$ Univ Rennes, Normandie Univ, CNRS, EthoS (Éthologie animale et humaine) - UMR 6552, F-35380

8 Paimpont, France

$9 \quad{ }^{2}$ IFCE ENE, Saumur, France

10

*Corresponding author:

Clémence Lesimple

UMR 6552 Ethologie animale et humaine

Station Biologique de Paimpont

35380 Paimpont - France

lesimple.c@gmail.com, tel. +33223237766 , 


\section{ABSTRACT}

Horses, and in particular sport horses, remain housed predominantly in single stalls. One of the main reported reasons is the fear that they will become agitated and injure themselves and thereby impair their performance if released in paddocks. The hour spent daily at work is also assumed to be sufficient to satisfy the horses' needs for locomotion. Growing scientific evidence shows that single stall housing has negative consequences on horses' welfare and that time for free movement is necessary. Our aim was to assess the feasibility of allowing sport horses used to staying permanently in their stall (except for 1hour riding/day) daily free time in a paddock and to evaluate its potential impact on their welfare using two behavioural reliable indicators (stereotypic behaviours and ear position), as well as selected blood parameters (blood cell count, oxytocin and serotonin concentrations). Two experiments were conducted on the same site. The first experiment evaluated sport horses' habituation to the novel situation of daily sessions in a paddock, and recorded welfare indicators in their stall before and during the experiment, comparing horses that were taken outdoors (experimental) and those that stayed in their stall (control). The second experiment evaluated the impact of this daily free time in a paddock on horses' welfare and its durability, focusing on positive indicators.. Behavioural observations in paddocks showed that even horses that had never experienced free movement outside their stall habituated rapidly to this situation. The presence of hay in the paddock, may have speeded up habituation. Their restricted living conditions were associated with abnormalities in blood cell count that were not overcome during the time of daily paddock sessions but behavioural indicators showed that their welfare improved. In the second study, the experimental horses' welfare improved during the paddock release period, in particular their stereotypic behaviours decreased and oxytocin levels increased. No effects on serotonin concentrations could be evidenced. These effects were directly associated with being in paddock, as the indicators returned rapidly to their previous levels indicating compromised welfare when the paddock release sessions stopped. In conclusion, it can be recommended to release sport horses for free movement in paddocks as welfare is improved and subjective assessment by caretakers indicated minimal risks.

Keywords: horse, housing, free movement, horse welfare, stereotypic behaviour, oxytocin 


\section{I-INTRODUCTION}

Under natural conditions, horses' home ranges vary in size according to resource availability (up to $250 \mathrm{~km}^{2}$ in arid areas, Waring, 2003). This species has evolved to adapt to an almost permanent slow locomotion, mostly when feeding. In the horse industry, particularly for sport horses, constant single stall housing ( $>20 \mathrm{~h} /$ day) is still predominant, despite its proven negative impact on horses' welfare. Beyond social constraints horses housed in individual stalls are deprived of free movement, i.e. slow walk observed quasi-permanently under natural conditions (e.g. Waring, 2003). Most domestic animals, including horses, show a rebound effect when released in larger spaces, with high locomotor patterns and excitement components (Albentosa and Cooper, 2004; Lesimple et al., 2011). Spatial confinement is associated with restriction of the expression of specific behaviours and thus impairing their welfare (Dawkins, 1988; Dixon et al., 2010). Captive laboratory animals, when kept under restricted spatial conditions, develop particular types of abnormal behaviours including stereotypic and abnormal repetitive behaviours $(\mathrm{SB} / \mathrm{ARB})$ that have been interpreted as attempts to flee (mice: Lewis and Hurst, 2004; Würbel et al., 1996; 1998; starlings: Feenders, 2012; Coulon et al., 2015; non-human primates: Draper and Bernstein, 1963). Similarly,single stall housing of horses has been shown experimentally to be a factor eliciting rapid emergence and the prevalence of abnormal repetitive behaviours (Visser et al., 2008) and identified by questionnaire-based (e.g. McGreevy et al., 1995) and observational (e.g. Lesimple et al., 2016) epidemiological studies. Reports suggest that weaving, a well-known locomotor stereotypic behaviour reflects the frustration of not being able to go out of the stall (Mills, 2005). SB and other indicators of compromised welfare are associated with changes in horses' learning abilities (e.g. Hausberger et al., 2007; Parker et al., 2009, see Hausberger et al., 2019 for review) and attentional impairments (Rochais et al., 2016) potentially leading to a drop in performance that can become problematic for sport horses.

A daily training session is generally considered sufficient to satisfy horses' needs in terms of locomotion. Nevertheless, Christie et al. (2006) reported that the frequency of SB/ARB of stall-housed riding horses increased with time spent working (either ridden or harnessed), whereas other authors (e.g. Lesimple et al., 2016) showed that it decreased when horses benefited regularly from several hours for free movement. Moreover, when given the choice, animals prefer to go to a larger arena 
(cattle: Bak Jensen et al., 1999) and are even ready to work actively to gain access to larger spaces (laboratory mice: Sherwin et al 2003, hens: Nicol, 1989; Lagadic and Faure, 1987). In choice tests, horses significantly preferred going to a paddock to staying in their stall, but also significantly preferred to go back to their stall to a forced 20-minute exercise on a treadmill (Lee et al., 2011). Similarly, when faced with an obstacle to reach food, leisure horses significantly preferred to go around the obstacle and the motivation of both leisure and sport horses to jump decreased with the obstacle's height (Gorecka-Bruzda et al., 2013). Thus, horses clearly appear motivated to gain free exercise but avoid, when possible, forced locomotion, maybe because it involves higher locomotion patterns (trotting, jumping). These preferences and observations of compromised welfare when horses are constantly in stalls outside work converge to indicate that free movement (at least part time) is a behavioural /physiological need. As mentioned by Popescu et al. (2014), many owners consider that a working horse does not need free exercise but rather needs rest to save and rebuild energy for work, although there are many arguments against this false belief. Due (2006) summarized guidelines proposed by different European associations for the protection of horses and veterinary associations, they state that "...the daily free running out ... has a positive influence on the general health, especially on the respiratory tract, the locomotor system as well as on the immune system and helps preserving health. Daily work, training machines (treadmill/horse walkers) are no adequate replacement for the free running out." At present, there is no legal frame concerning free exercise for horses. The European Union official text (Council Directive 98/58/CE, L221/26/7 of the directive) states that "the freedom of movement of an animal [...] must not be restricted in such a way as to cause it unnecessary suffering or injury" but also that continuous or regular confinement is accepted if "appropriate space is given to fulfil the physiological and ethological needs in accordance with established experience and scientific knowledge". Large discrepancies also arise between national countries' laws (Owers and Tabram, 2005), which all state that an animal has to be able to lie down and to stand up (French rural code 2018, Hungarian law on animal welfare and protection 1998, Polish Animal Protection Act 2010, Swiss Ordinance on animal protection 2018), but may even forbid outdoor housing in the absence of a shelter including (French rural code 2018) or not (Swiss 
Ordinance on animal protection 2018) natural shelter (e.g. hedges). There is therefore a real need for further scientific evidence.

Beyond the ethical question of animal welfare, performance level of sport horses is important and time spent outside work may have an influence. Maintaining muscular activity after an intense exercise (also called active recovery) has proven efficacious to improve human athletes' recovery time (metabolic return to basal state, e.g. Greenwood et al., 2008; Kalen et al., 2017) and subsequent performance (Monedero and Donne, 2000). Indeed, keeping up mild aerobic and stretching activities was shown to fasten lactate removal and to increase its potential use as fuel for heart and working muscles (e.g. Gisolfi et al., 1966; Menzies et al., 2010). To our knowledge, the impact of recovery techniques on horses' recovery time and subsequent performance has not been investigated. However, as the metabolic consequences following intense exercise are similar for horses and humans (e.g. Assenza et al., 2014; Binda et al., 2016), active recovery is likely to have positive consequences in terms of recovery time and performance. Thus offering regularly sport horses time for free locomotion should improve their welfare, help them recover after an effort and maintain their physical capacities. The main reasons why most sport horses do not benefit from free locomotion times in paddocks are: 1the fear potential injuries (e.g. wounds and lameness) could occur if they become more agitated after being released, and thus impair their subsequent performance, and 2- the belief that performing horses need rest more than free exercise (Popescu and Diugan 2017).

This study aimed: (1) to assess the feasibility (in terms of habituation and potential harm) of allowing adult sport horses that had always been housed in single stalls daily sessions in a paddock, and (2) to evaluate the consequences of these daily sessions on their welfare and the durability of the effects. Two experiments were carried out successively. The first experiment, including 24 horses, evaluated the feasibility of a daily paddock release. More precisely, potential habituation to this novel situation and the short-term impact on the horses' welfare (measured in stall) were assessed. The second experiment, including 20 horses, evaluated the impact of daily periods of free time in paddock on horses' welfare, focusing in particular on positive indicators. We assessed the durability (after cessation of the free release period) of the potential effects. Both studies compared pairs of horses: one experimental (i.e. released daily in paddock) to one control (i.e. remaining in stall). Observations were 
performed before (study 1 and 2), during (study 1 and 2) and after (study 2) the period of regular paddock release. The reactions of the experimental horses during their daily release in a paddock were recorded (studies 1 and 2). Moreover, their welfare, as a chronic state (e.g. Broom, 1991), was assessed when horses were in their usual stall, using behavioural (i.e. stereotypic behaviours, postural indicators), as well as physiological parameters (i.e. complete blood cell count, oxytocin and serotonin plasma levels).

Humans' total blood cell counts have proven to be able to indicate depression (higher counts of white and red blood cells) and anxiety syndromes (e.g. Köhler Forsberg et al., 2017; Shafiee et al., 2017). Numbers of cows' red blood cells and lymphocytes increased under spatial restriction (Nakajima et al., 2018). Working horses' neutrophil/leucocyte ratios were negatively correlated with welfare (Popescu and Diugan, 2017), and many riding school horses living under restricted conditions were found to suffer from anaemia and abnormal neutrophil levels (Pawluski et al., 2017). The relationship between chronic stress and cortisol levels is less straightforward with, on one hand, rapidly changing individual cortisol levels (e.g. McBride and Cuddeford, 2001), and, on the other hand, heterogeneous results from one study to another. Some studies reported higher (e.g. McGreevy and Nicol, 1998; Bachmann et al., 2003) or lower levels (Pawluski et al., 2017) of cortisol when horses' welfare was compromised, but many other authors found no significant differences neither in salivary nor in plasma cortisol levels between horses' presenting stereotypic and non-stereotypic behaviour (Pell and McGreevy, 1999; Clegg et al., 2008; Hemman et al., 2012; Fureix et al., 2013). Other physiological markers may be of interest: humans' low plasma serotonin levels are associated with the prevalence of depression (Young, 2007) and aggressiveness (see Wallner and Machatschke, 2009 for a review), and high plasma oxytocin levels were shown to enhance the processing of positive emotions (DiSimplicio et al., 2008) and increase generosity (Zak et al., 2007). Several studies have shown that aggressive dogs present lower blood serotonin levels (Cakiroglu et al., 2017; Jacobs et al., 2007; Leon et al., 2012; Rosado et al., 2010), while positive interactions with humans are associated with increase of serotonin (Alberghina et al., 2017) and oxytocin (Nagasawa et al., 2015) levels.

157 Therefore, we focused on complete blood cell counts, but also on serotonin and oxytocin levels as potential physiological indicators of positive emotions. 


\section{II-GENERAL METHODS}

\section{1-General procedure (Fig. 1)}

This experimentation involved two successive studies (Fig. 1). The first experiment (March $12^{\text {th }}$ to April $6^{\text {th }} 2018$ ) assessed horses' behavioural reactions and habituation to paddock release, and the impact of these daily release on selected blood parameters (complete blood cell count, sedimentation rates as well as oxytocin and serotonin levels before and after the period of daily release) and behavioural welfare expressions (SB/ARB, ear positions). The second experiment (May $14^{\text {th }}$ to June $15^{\text {th }} 2018$ ) assessed the impact during and after (cessation) the daily release period. We included measures of oxytocin and serotonin levels as potential positive physiological indicators.

Two types of comparisons were used: (1) between the different phases, i.e. during the daily release periods versus outside daily release periods, and (2) between experimental (i.e. released daily in paddock) and control horses (i.e. stayed in stall).

We hoped to assess the impact of daily paddock free sessions on the horses' performance. Unfortunately, for sanitary reasons, all the competitions in the region were stopped for 2 months shortly after our experiments so we could not evaluate the horses' performance after the experiments.

\section{2-Animals}

These experiments took place at the "Ecole Nationale d'Equitation" (ENE) in Saumur (France). In all, 29 horses (16 geldings and 13 mares, 9 to 15 years old), mostly French Saddlebreds (N=26; Anglo Arabians: N=3) were observed. All horses were used in courses for riding instructors. They had all been in this same facility for at least one year and most had arrived when 4 or 5 years old. Management conditions were thus identical for all horses: single stall housing with one hour riding (or occasionally automated horse walker) per day, and none of them had had previous experience of free time in a paddock. They were housed in an indoor barn with no outdoor openings, but half side walls replaced with grids, enabling sight and nose to nose contact with their two neighbours. A grid above their door enabled them to see their neighbours across the corridor: they could therefore see more than 5 neighbours ( 1 on each side and at least 3 in front). They were kept in straw bedded single stalls equipped with automatic drinkers. The stalls were cleaned every morning and fresh straw was added. 
All horses were fed commercial pellets, using an automated feeding system that controlled the distribution of pellets in the individual feeders, three times a day (7.30 am, $11.30 \mathrm{am}$, and $5.30 \mathrm{pm})$. The amount given $(\mathrm{X} \pm \mathrm{SE}=3.0 \pm 0.0 \mathrm{~L}$; range $=2.0-4.0 \mathrm{~L})$ was determined by the facility's veterinarian according to the size and mass of each individual. The amount of hay provided per day (9 $\mathrm{kg}$ for all horses) was also determined by the veterinarian and distributed half in the morning (8am), and half in the afternoon $(15 \mathrm{pm})$. For both studies, horses were paired with their closest counterpart (in terms of sex, age, breed and caretaker). The two horses of each pair were then randomly allotted, one to the experimental (went to paddock) group and one to the control (stayed in stall) group. At ENE, the health routine procedure consists in a monthly examination by the facility's veterinarian. None of the horses involved in our study presented any declared pathological disorder at the time of the experiments.

\section{3-Paddock release procedure}

Two adjacent paddocks with sandy soil $\left(190\right.$ and $\left.220 \mathrm{~m}^{2}\right)$ separated by a $1 \mathrm{~m}$-wide path and located in the immediate surroundings of the horses'stables (to facilitate the caretakers' work) were used for this study. Each paddock was equipped with an automatic water-trough and a slow-feeder (Pacefeeder®, Bray, Ireland) full of hay in order to provide ad libitum access to water and fibre diet. The amount of hay distributed in the stall was lowered for the experimental horses as they had access to hay in paddocks, so as to insure that horses in both groups received the same quantity of roughage.

The experimental horses were released in paddock for 39-62 minutes $(\mathrm{X} \pm \mathrm{es}=46 \pm 1 \mathrm{~min}$, no significant differences between horses: Kruskall Wallis Anova, $\chi=10.2, \mathrm{p}=0.5$ ) per day, 5 days a week (from Monday to Friday), between $8 \mathrm{am}$ and $4 \mathrm{pm}$ and in pairs with one horse in each paddock (same pair every day, same caretaker for horses of a same pair). They could see, hear and smell their neighbours, but physical contact was not possible. The horse's location of release (Right paddock, $\mathrm{R}$ or Left paddock, L), as well as the release time slot were shifted every day; thus, a horse that went out at 8 am to R paddock on Monday went at 9am to L paddock on Tuesday, and so on. As for a given pair horses' arrival times differed a few minutes, only the periods when both horses had a neighbour were analysed here. 
At the end of each study, caretakers were asked to give their subjective perceived feasibility (in terms of risks and handling).

\section{4-Observations in the paddocks (experimental horses)}

The behaviours of the horses while in the paddocks were recorded using two camcorders (JVC Full HD EverioR 60x) placed in each paddock, at two opposite angles (close to the entrance and close to the slow-feeder) in order to have a full visibility of the horse, whatever its position in the paddock. The videos were analysed subsequently, using the Instantaneous Scan Sampling method (Altman, 1974) with a scan every 2 minutes. In addition, all occurrences of rare/short behaviours and postures were recorded (Altman, 1974). The activities and behaviours observed are described in Table 1.

\section{5-Welfare evaluation in stalls (experimental and control horses): behavioural and postural}

\section{indicators}

All horses were observed in their own individual stall during the week prior to the beginning of the paddock releases and then during the three (Study 1) or two (Study 2) weeks of daily paddock release sessions.

The same observer (LRB, the experimenter) recorded all the observations in the two studies using classical ethological methods. Direct observations of behaviour using Instantaneous Scan Sampling were performed as this method reflects reliably individual time-budgets (i.e. time spent in different activities, Altman, 1974). The procedure used for the present study was similar to that used in other studies and proved successful in assessing welfare (Benhajali et al., 2010; Heleski and Murtazashvili, 2010; Lesimple et al., 2019; Rochais et al., 2018): twice a day, once in the morning (between 6am and 7.15am) and once in the evening (when horses had hay, between $3 \mathrm{pm}$ and 4.30pm), the experimenter walked slowly and silently along the stalls and noted the behaviour and posture (see below) of each horse, at the instantaneous time of observation, that is every $5 \mathrm{~min}$ (time between 2 circuits). Horses were used to see people walking in the corridor at the time these observations were made (riders, students, caretakers) and they did not show any change of activity when the experimenter walked in front of their stall. Moreover, both experimental and control horses lived in the same stables and thus were exposed to the same observational procedure. In order to ensure that time between two observations of the same horse was constant, they were always observed in the same order. 
Occasionally, a horse had to leave its stall during the observation period (for care or work), leading to

small discrepancies in the numbers of observations per horse.

The observations concentrated on two indicators of compromised welfare:

- Presence of SB/ARB related to chronic stress for captive and for domestic species (Mason, 1991) known to be associated with impaired fertility (Benhajali et al., 2014) and altered cognitive abilities (review in Hausberger et al., 2019) in horses. For an activity to be considered a SB/ARB, the sequence had to be repeated at least three times in succession and observed five times, independently of the period of observation (Lesimple et al., 2016).

- ear position (backwards, forwards, asymmetrical, see Fureix et al., 2010) when foraging, ears backwards in this context reflecting impairment of welfare (e.g. Hausberger et al., 2016; Henry et al., 2017; Fureix et al., 2010)

\section{6-Physiological parameters}

As a modification of their welfare state may impact the horses' physiology (e.g. Pawluski et al., 2017; Popescu and Diugan, 2017), we investigated the relationships between the horses' welfare states, paddock releases and some blood parameters (complete blood cell count, serotonin and oxytocin blood levels).

Blood sampling is part of the routine sanitary control of horses at the ENE, to monitor horses' rehydration, muscular condition and food intake adequacy with exercise. Therefore the Comité Rennais d'Ethique en matière d'Expérimentation Animale considered that no approval was required, since blood sampling was part of the usual examinations and not conducted especially for our experiment. It was undertaken with the approval of the facility's senior veterinary and conducted by the usual experienced technician (LB) in charge of blood sampling at the ENE. All horses were used to the blood sampling procedure and accepted it well during both studies. It is worth nothing that particular attention was given by the technician to minimize potential aversive effects of blood sampling, which was confirmed here by the absence of any reaction by the horses. The entire procedure, from halter fitting to the end of the sampling session lasted less than one minute. Besides, horses were systematically given a food reward (one sugar lump) at the end of each sampling session. 
The following analyses were performed: complete blood cell counts (CBCC) and sedimentation rates

272 (at $0.5 \mathrm{~h}$ and $1 \mathrm{~h}$ ) were analysed by the veterinary laboratory LABEO Franck (Caen, France) for study 1

273

274

275

and the $\mathrm{CBCC}$ results were compared to physiological norms for sport horses provided by LABEO. As the results of study 1 showed positive improvement of horses' welfare we chose to focus study 2 on potential indicators of positive emotions, i.e. plasma levels of oxytocin and serotonin (Alberghina et al, 2017; Nagasawa et al, 2015).

\section{7-Statistical analyses}

As data were not normally distributed (Shapiro-Wilk test, $\mathrm{p}<0.05$ ), non-parametric statistical tests were used. The statistical tests were performed using Statistica ${ }^{\circledR} 13$ (Statsoft, Tulsa, USA).

Friedman and subsequent Wilcoxon tests were used to evaluate the behavioural and physiological changes in relation to time, e.g. between the first days (D1 to D4) and the last days (D13 to D14) of the daily paddock release period. Wilcoxon tests were used to compare physiological data before and after the daily release period.

Mann-Whitney $\mathrm{U}$ tests (MW U test) were used to compare the behaviour and physiological parameters of experimental horses and control horses.

\section{III- STUDY 1: RELEASE OF SPORT HORSES IN A PADDOCK: FEASABILITY AND IMPACT ON WELFARE}

This study aimed to assess the potential habituation of horses to the novel situation of the possibility for free movement, as well as its short-term impact on their welfare during the period of daily release

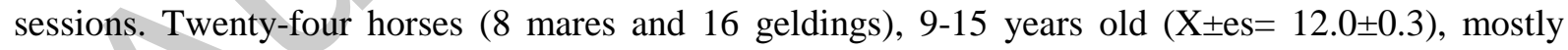
French Saddlebreds $(\mathrm{N}=21)$ (Anglo-Arabian, $\mathrm{N}=3$ ) took part in this study. The experimental horses were released daily during three consecutive weeks (14 paddock releases per horse). Moreover,

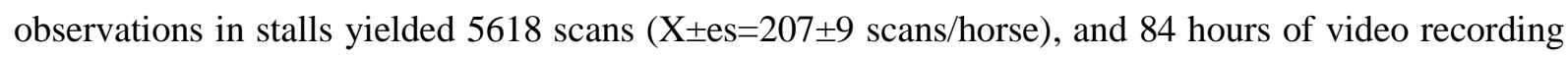
in paddocks were analysed $(\mathrm{N}=1599$ scans; $135.9 \pm 5.3$ scans/horse). Based on the facility routine, blood samples were taken between 9 and 11.30am on March $8^{\text {th }}$, i.e. before the start of the experiment, and on April $10^{\text {th }}$, i.e. at the end of the experiment. In addition to routine sampling, five millilitres of blood were collected in heparinised EDTA K3 tubes (BD Vacutainer®, Becton, Dickinson \& 
Company, Franklin Lakes, USA), then placed in a refrigerator at $4^{\circ} \mathrm{C}$ before being sent to a veterinary laboratory for analysis (LABEO Franck Duncombe, Caen, France) within the day. They were used to assess the horses' complete blood cell count $(\mathrm{CBCC})$ and sedimentation rates that were not usually controlled.

\subsection{Results}

\subsubsection{Behaviour in the paddock (experimental horses)}

On day 1 (D1) behaviours reflecting alarm (vigilance posture) and excitement (e.g. snores, blows, kicking, rearing, active locomotion) were frequent, but their frequency decreased quickly over the following days so that they were almost absent after D4 and remained rare until D14 (Friedman F, p $<0.005$ in all cases; Fig. 2). In contrast, feeding activity was rare on days 1 to 4 (Friedman test, $\mathrm{p}>0.05$ ), but increased significantly on the last experimental days (Friedman test: D1-D14, $<<0.01$ ). Excitement/alert behaviours decreased significantly and time spent eating increased significantly between D1 and D14 (Wilcoxon tests: respectively $\mathrm{p}<0.01$ and $\mathrm{p}<0.005$ ), whereas no significant differences in behaviour between D13 and D14 could be evidenced (Wilcoxon tests, p>0.05 in all cases), suggesting stabilization of horses' behaviours.

Subjective reports by the caretakers indicated no particular difficulty in leading horses to the paddocks or back to the stalls, and no major injury, that would have requested special care or overt lameness.

3.1.2. Impact of free time in paddock on horses' welfare state (evaluated in stalls)

In order to assess the impact of the daily paddock release sessions on horses' welfare, the behaviours of the experimental and control (remaining in stalls) horses were compared before and during the paddock release period.

\subsubsection{Stereotypic / Abnormal repetitive behaviours (SB/ARB)}

The prevalence of SB/ARB did not differ between the two groups before the paddock release period $\left(\mathrm{N}_{\text {Experimental }}=12, \mathrm{~N}_{\text {Control }}=12, \bar{X}_{\text {Experimental }} \pm \mathrm{se}=12.88 \pm 1.9, \bar{X}_{\text {Control }} \pm \mathrm{se}=13.13 \pm 2.6, \mathrm{MW} \mathrm{U}\right.$ test, $\mathrm{U}=85.5, \mathrm{p}=0.63$ ). At the end of the three weeks of daily paddock release, the experimental horses tended to produce significantly less $\mathrm{SB} / \mathrm{ARB}$ than the control horses $\left(\bar{X}_{\text {Experimental }} \pm \mathrm{se}=9.96 \pm 2.2\right.$, $\bar{X}_{\text {Control }} \pm \mathrm{se}=17.96 \pm 3.2$, MW U test, $\left.\mathrm{U}=41, \mathrm{p}=0.07\right)$. 


\subsubsection{Ear positions during feeding}

The short-term positive impact of paddock release was confirmed by ear position records: times spent with ears backwards by the experimental horses while foraging decreased significantly during the first week of paddock release (Friedman and Wilcoxon tests, $p<0.05$ in all cases) whilst it did not vary for control horses (Friedman test, $\chi=1.17, \mathrm{p}=0.5$ ) (Fig. 3). Thus, whilst times spent with ears backwards did not differ significantly between the two groups of horses before the paddock release period $\left(\bar{X}_{\text {Experimental }} \pm \mathrm{se}=47.40 \pm 5.2, \bar{X}_{\text {Control }} \pm \mathrm{se}=38.92 \pm 5.8\right.$, MW U test, $\left.\mathrm{U}=52 \mathrm{p}=0.26\right)$, the experimental horses spent significantly less time than controls with ears backwards while foraging after three weeks of daily paddock sessions $\left(\bar{X}_{\text {Experimental }} \pm \mathrm{se}=21.73 \pm 5.2, \bar{X}_{\text {Control }} \pm \mathrm{se}=40.08 \pm 7.2\right.$, MW U test, U=37, $\mathrm{p}=0.04)$ (Fig. 3).

\subsubsection{Horses' welfare and complete blood cell count (CBCC) parameters}

All horses involved in this study presented blood cell count abnormalities (e.g. abnormal count of red and white blood cells). For example, the mean corpuscular haemoglobin values were abnormally low for the whole population, suggesting anaemia, while $92 \%$ of horses $(\mathrm{N}=22 / 24)$ presented abnormally low concentrations of leucocytes (Table 2). No effects of free time in paddock could be evidenced: CBCC parameters did not differ significantly between before and after the paddock period (Mann Whitney $\mathrm{U}$ tests, $\mathrm{p}>0.1$ in all cases).

It is worth noting that before the experiments, stereotypic horses presented higher sedimentation rates at $0.5 \mathrm{~h}$ and $1 \mathrm{~h}$ than non-stereotypic horses (MW U tests, $\mathrm{N}_{\mathrm{SB}}=20, \mathrm{~N}_{\mathrm{Non}-\mathrm{SB}}=4, \mathrm{U}_{1}=9, \mathrm{U}_{2}=11$, $\mathrm{p}=0.02$ and $\mathrm{p}=0.03$ respectively).

\subsection{Conclusion}

Thus, these sport horses habituated rapidly to the novelty of daily release in a paddock, and despite excitement behaviours at first, did not come to any harm. Moreover, some improvement of experimental horses' welfare could be observed in the stalls, suggesting that daily free time in a paddock was beneficial in the short-term. The physiological data revealed that their restricted living conditions were in any case impacting the horses' health although the paddock release period did not have any impact on CBCC parameters. Maybe given the horses' condition before the experiment, the duration of the experiment of daily paddock release was not last long enough. 


\section{IV- STUDY 2: IMPACT OF FREE TIME IN PADDOCK ON HORSES' WELFARE AND}

357

\section{ITS DURABILITY}

The second experiment focused on the impact of time for free locomotion on horses' welfare and its impact over the two following weeks, after cessation of the daily release in paddock. We had the possibility to observe the behaviour of some horses that changed status (experimental/control) between the two experiments. Twenty horses ( 7 mares and 13 geldings), 9 to15 years old $(\mathrm{X} \pm \mathrm{es}=12 \pm 0.4$ ), mostly French Saddlebreds ( $\mathrm{N}=17$; Anglo-Arabian: $\mathrm{N}=3$ ) were used. Fourteen ( 7 pairs experimental/control) of these horses that had been involved in the first study were available, but we reversed their status (experimental or control): the 7 study 1 control horses now had daily access to paddock, whereas the 7 study 1 experimental horses became controls, i.e. remained in their stall. Although the distribution between the experimental and control groups had been random in study 1 , the group of these 14 horses was automatically reversed for study 2 . In order to have a larger sample and thus increase statistical power, 6 more horses ( 5 experimental and 1 control assigned randomly) were added for study 2 . There were therefore twelve experimental and 8 control horses. The duration of the paddock release period was limited to two week ( 9 paddock releases) due to logistic constraints of the facility. Thus, horses were observed 1 week prior to the experiment, one week during the paddock release period and then for 2 weeks in their stalls after the cessation of paddock release. In all, we recorded a total of 6357 scans in the stalls (range: $288-347, \mathrm{X} \pm \mathrm{es}=322 \pm 4.6$ scans/horse). Some horses had to leave their stall during the observations (care, work), which explains discrepancy in numbers of observations per horse.

Horses' oxytocin and serotonin plasma levels were assessed. As for study 1, according to the facility routine procedures, blood sampling was performed between 9 and 11 am on May $15^{\text {th }} 2018$, i.e. before the paddock release period, and on June $1^{\text {st }} 2018$ i.e. after the paddock release period and ten millilitres $(2 \times 5 \mathrm{~mL})$ of blood were collected additionally and put in two heparinised EDTA K3 tubes (BD Vacutainer®, Becton, Dickinson \& Compagny), then placed in crushed ice with salt. Tubes were centrifuged $15 \mathrm{~min}$ at $3000 \mathrm{~g}$ to extract the plasma $(6-9 \mathrm{~mL} / \mathrm{blood}$ sample), which was then harvested and frozen at $-20{ }^{\circ} \mathrm{C}$ pending completion of analysis. Analyses were performed within three 
weeks following collection by the same technician specialized in hormonal analyses at the Veterinary School (ONIRIS) in Nantes (France). In order to check the effects of variations due to circadian rhythm of secretion, horses' blood samples were collected in the same order on both dates. Hormonal levels were assessed using commercially available Elisa kits specific for oxytocin and serotonin measurements.

\subsection{Results}

\subsubsection{Welfare assessment in stall}

Frequencies of SB/ARB decreased significantly (Friedman test $\mathrm{S}-1 / \mathrm{S} 3, \chi=9, \mathrm{p}=0.03$; Wilcoxon tests: S-1/S1, Z=2.36, p=0.02; S1/S4, Z=1.7, p=0.07, not significant in the other cases) (Fig. 4) and of the time spent with ears backwards in the experimental group (\% time spent with ears backwards, Friedman tests, $\chi=36.7, p<0.001)$ during the daily release period, while no changes could be evidenced in the control group (Fig. 6). These results were confirmed for the 7 pairs of horses from study 1, showing that the study 2 experimental horses (controls in study 1 ) tended to express less SB/ARB (Friedman test, $\chi=6.9, \mathrm{p}=0.07$ ), and spent significantly less time with ears backwards (Friedman test, $\chi=16.1, \mathrm{p}=0.001)$ during the paddock release period. This behavioural flexibility confirms clearly the impact of sessions of free exercise. In parallel, experimental horses spent more time with ears forwards during the daily release period (Friedman test, $\chi=14.1, \mathrm{p}=0.003$ ).

However, this effect was only short-term as these two indicators increased during the first week after the daily paddock sessions had stopped, and still more so during the second week, reaching values above the basal level observed before the paddock release period (increased frustration?) (Fig.

$$
\text { 4, Fig. 5). }
$$

\subsubsection{Hormonal measures}

Serotonin levels before and after the paddock release period (Wilcoxon test, $\mathrm{p}>0.05$ ) were similar and no differences could be evidenced between the experimental and control groups (MW U test, $p>0.05)$. However, oxytocin levels of experimental horses increased significantly after the period of daily paddock release (Wilcoxon test, $\mathrm{t}=1.9, \mathrm{p}=0.05$; Fig. 6).

\subsection{Conclusion}



major and, associated with an increase of oxytocin levels, suggests a possible increase of positive

412

413 emotions. However, their cessation was associated rapidly with an increase of the values of indicators of compromised welfare. Here again, subjective assessments by caretakers indicated no major risk or difficulty associated with this procedure.

\section{V-DISCUSSION}

Our analyses of horses' behaviours showed (1) that daily release of inexperienced (with paddock) adult sport horses in a paddock is feasible, as they habituate rapidly to this situation and (2) that regular time for free movement has a clear positive impact on horses' welfare and emotional state. Thus, these times for free movement were associated with an immediate decrease of indicators of compromised welfare (SB/ARB and time spent with ears backwards), but also with an increase of the levels of plasma oxytocin in experimental horses. These results are remarkable, since the horses were released alone and the duration of the daily release sessions were very short (39-62 min.) and over limited periods of time (14 and 9 days). However, this was probably not enough to improve blood parameters which showed abnormalities before and still after the procedure. Further experiments should involve longer daily release sessions and longer periods of daily turnout. The presence of hay in the paddock might have been a major factor facilitating the horses' habituation to this novel situation.

During the first days of the release period, all the experimental horses expressed some excitement (trot, canter and passage) and alarm (vigilance posture), confirming the high emotional arousal of single-stall housed horses when released in a larger space (Lesimple et al., 2011). However, this emotional arousal disappeared quickly and frequencies of quieter behaviours such as feeding and slow locomotion (walk) increased. This positive behavioural transition, leading to a more naturalistic timebudget (Waring, 2003), was probably further enhanced by the access to hay in the slow-feeder. Thus, both experimental and control horses had a semi-continuous access to hay, thus fulfilling their foraging needs (e.g. Benhajali et al., 2009; Goodwin et al., 2002; Rochais et al., 2018; Waring, 2003). In addition, being able to forage probably helped redirect the horses' focus, speed up their habituation and decrease the potential novelty stressor effect of the paddock situation. Subjective assessment by 
the familiar caretakers indicated no major problem associated with the procedure and the release in paddock never led to requirement of sanitary measures or vet examinations.

Constant single-stall housing is known to be detrimental for horses at any age (e.g. Heleski et al., 2002; Lesimple et al., 2016, Waters et al., 2002), while spending time in a paddock seems to reduce welfare impairment (McGreevy et al., 1995; Lesimple et al., 2016; Normando et al., 2002). Our observations show that even if it is only for short periods ( $1 \mathrm{~h} /$ day, 5 days a week, for 2 or 3 weeks) and without the presence of conspecifics daily access to a larger area enabling free movement led to a significant decrease of the values of indicators of compromised welfare (Mills, 2005; Wiedenmayer, 1996), while no significant changes in control horses' behavioural patterns were observed. This is in accordance with other studies conducted on captive animals showing a decrease of SB/ARB when animals were given access to larger spaces (parrots: Polverino et al., 2015; cheetahs: Quircke et al., 2012). Our results were confirmed by the data for the behaviour of the horses that were in the study 2 experimental group and had been in the study 1 control group: the positive impact of regular paddock release was not related to individual characteristics. Moreover, the values of compromised welfare indicators increased as soon as the period of daily paddock release was over, reaching and even, after two weeks, becoming above the pre-experiment basal level. Such rapid changes in the indicators of compromised welfare are in accordance with Lesimple et al.'s (2019) recent findings highlighting an immediate modification of the expression of SB/ARB in response to changes in stall architecture. Thus, in addition to the direct relationship found between welfare improvement and paddock release, our results highlight the importance of regular, uninterrupted access to periods for free movement.

The results of study 2 even suggest that daily paddock release may promote positive emotions. Thus, experimental horses' oxytocin levels increased after 5 days of paddock release while no such change was observed in the control horses. Authors generally consider that an increase of oxytocin blood levels is related to positive emotions, as reported for several species (e.g. humans: Feldman et al., 2010; Turner et al., 1999; dogs: Mitsui et al., 2011; Nagasawa et al., 2015; sheep: Laine et al., 2016). There is some controversy about the significance of oxytocin in terms of emotional valence as positive visual attention between humans and dogs is associated with an immediate increase of oxytocin levels (Nagasawa et al., 2015) whereas two recent studies suggest that humans' gentle 
handling of horses and lambs induces a decrease of oxytocin levels (Lansade et al., 2018; Coulon et al., 2013). A first possible explanation is that this discrepancy could be related to differences in hormonal sampling and analyses (Neumann, 2008) or the situations involved (changes in housing versus human-animal interactions and the interpretation of its impact on animals). A second hypothesis could be that in our study, the duration of the paddock release period was too short to elicit a modification of the basal level of oxytocin. Thus, the increase of blood oxytocin level would be related to the occurrence of short term positive events, here paddock release (Mitsui et al., 2011; Nagasawa et al., 2015). Our results did not reveal however any impact of paddock release on serotonin blood levels. Serotonin levels vary throughout the day (together with the functioning of the corticosteroid system), and are higher during the activity phase of an individual (rodents: Chalet, 2007). Exposure to stressors throughout the day impacts changes in serotonin levels (Chaouloff, 2000). Possibly, rather than a single sampling before and after the paddock release period, evaluation of the speed serotonin levels decline throughout the day would be more efficient to detect potential positive impacts of such periods for free movement on horses' serotoninergic system (see Daut and Fonken, 2019 for a review). On the other hand, despite the absence of any declared pathological disorders (monthly check-up by a dedicated senior veterinarian), as mentioned above, the horses in this study all presented important physiological disorders that remained after the paddock release period, as revealed by the CBCC analyses (e.g. $87 \%$ of the horses presenting low leucocyte levels). The short duration of the daily release period and the total duration of the release period seemed to be insufficient to improve the horses' internal state reflected by CBCC. The serotoninergic system could possibly require a longer period of daily paddock release to show an increase. Interestingly, our results show unusual relationships between the horses' welfare state and physiological data. Recently, Popescu and Diugan (2017) reported an increase of inflammation indicators (neutrophils/leucocytes ratio) together with alteration of working horses' welfare state, and riding school horses under constraining working conditions presented abnormal neutrophil levels (Pawluski et al., 2017). Thus, horses with $\mathrm{SB} / \mathrm{ARB}$ or that spent more time with ears backwards when foraging presented high rates of indicators of inflammation (e.g. sedimentation rate, white cells) showing a relationship between behavioural and postural indicators of compromised welfare and physiological disorders. 
Given the major positive impact of experimental paddock release on horses' behaviours, it would be interesting to determine whether longer release durations could have an impact on the horses' internal state (CBCC and serotonin levels). Moreover, free movement is not part of any current international regulation. The results of the present study, which add to the already existing scientific literature on other types of ridden horses (e.g. Bachman et al., 2003; Lesimple et al., 2011, 2016) suggest that requirement for sessions for free movement should be added. Finally, as social contacts are a crucial need it would be interesting to repeat this experiment with horses released in pairs or in groups. Overall, this study highlights the fact that providing sport horses some time for daily free locomotion (ideally with roughage/grass resources) is possible and incurs no particular risks and that it is an essential requisite for promoting good welfare for horses.

\section{VI-ACKNOWLEDGEMENTS}

We are most grateful to the staff of the "Ecole Nationale d'Equitation" and in particular to the stable manager Christine Loyen, and to the caretakers, for their help during the study. Dr Goupil helped with and supervised physiological samplings on site. We thank Caroline Berder, at Oniris, for her help with the hormonal analyses. Drs Ann Cloarec and Katie Collier improved the English of the manuscript. Funding was provided by the Université de Rennes 1 (France), the CNRS (France) and the COST-IFCE ("Way-Out” project, France).

\section{VII- REFERENCES}

Albentosa, M., Cooper,J., 2004. Effects of cage height and stocking density on the frequency and comfort behaviours performed by laying hens housed in furnished cages. Anim. Welf. 13, 419424.

Alberghina, D., Rizzo, M., Piccione, G., Giannetto, C., 2017. An explanatory study about the association between serum serotonin concentration and canine-human social interactions in shelter dogs (Canis familiaris). J. Vet. Behav. 18, 96-101.

Altman, J., 1974. Observational study of behaviour: sampling methods. Behaviour 9, 227-265. 
Bak Jensen, M., 1999. Effects of confinement on rebounds of locomotor behaviours of calves and heifers, and the spatial preferences of calves. Appl. Anim. Behave. Sci. 62, 43-56.

Bachmann, I. Audiger, L., Stauffacher, M., 2003. Risk factors associated with behavioural disorders of crib-biting, weaving and bx walking in Swiss horses. Equine Vet. J. 35, 158-163. https:// doi.org/10.2746/042516403776114216.

Bachmann, I., Bernasconi, P., Herrmann, R., Weishaupt, M.A., Stauffacher, M., 2003. Behavioural and physiological responses to an acute stressor in crib-biting and control. Appl Anim Behav Sci. 82, 297-311. https://doi.org/10.1016/S0168-1591(03)00086-8.

Benhajali, H., Richard-Yris, M.A., Ezzaouia, M., Charfi, F., Hausberger. M., 2009. Foraging opportunity: a crucial criterion for horse welfare? Animal 3, 1308-1312. https://doi.org/10.1017/S1751731109004820.

Benhajali, H., Ezzaouia, M., Lunel, C., Charfi, F., Hausberger, M., 2014. Stereotypic behaviours and mating success in domestic mares. Appl. Anim. Behav. Sci. 153, 36-42. https://doi.org/10.1016/j.applanim.2014.01.002.Broom, D., 1991. Animal welfare: concepts and measurement. J. Anim. Sci. 69, 4167-4175.

Cakiroglu, D., Meral, Y., Sancak, A., Cifti, G., 2017. Relationship between the serum concentration of serotonin and lipids in aggression in dogs. Vet.Rec. 161, 59-61.

Christie, J., Hewson, C., Riley, C., McNiven, M., Dohoo, I., Bate, L., 2006. Management factors affecting stereotypies and body condition score in nonracing horses in Prince Edward Island. Can.Vet.J. 47, 136-143.

Challet, E., 2007. Minireview: Entrainment of the suprachiasmatic clockwork in diurnal and nocturnal mammals. Endocrinology 148, 5648-5655.

Chaouloff, F., 2000. Serotonin, stress and corticoids. J. Psychopharmacol. 14, 139-151. https://doi.org/10.1177/026988110001400203.

Clegg, H.A., Buckley, P., Friend, M.A., McGreevy, P.D., 2008. The ethological and physiological characteristics of cribbing and weaving horses. Appl Anim Behav Sci. 109, 68-76. https://doi.org/10.1016/j.applanim.2007.02.001. 
Coulon, M., Nowak, R., Andanson S., Ravel, C., Guy Marnet, P., Boissy, A., Boivin, X., 2013. Human-lamb bonding: Oxytocin, cortisol and behavioural responses of lambs to human contact and social separation. Psychoneuroendo. 38, 499-508. https://doi.org/10.1016/j.psyneuen.2012.07.008.

Coulon, M., Henry, L., Perret, A., Cousillas, H., Hausberger, M. George, I., 2014. Assessing video presentations as environmental enrichment for laboratory birds. PLoS ONE, 9, e96949. https://doi.org/10.1371/journal.pone.0096949.

Daut, R. Fonken, L., 2019. Circadian regulation of depression: A role for serotonin. Front. Neuroendocrin.100746. https://doi.org/10.1016/j.yfrne.2019.04.003.

Dawkins, M., 1988. Behavioural deprivation: A central problem in animal welfare. Appl. Anim. Behav. Sci. 20, 209-225. https://doi.org/10.1016/0168-1591(88)90047-0.

DiSimplicio, M. Massey-Chase, R. Cowen, P.J., Harmer, C.J., 2008. Oxytocin enhances processing of positive versus negative emotional information in healthy male volunteers. J. Psychopharm. 23, 241-248. https://doi.org/10.1177/0269881108095705.

Dixon, L., Hardiman, J., Cooper, J., 2010. The effect of spatial restriction on the behaviour of rabbits (Oryctolagus cuniculus). J. Vet. Behav. 5, 302-308. https://doi.org/10.1016/j.jveb.2010.07.002.

Draper, W., Bernstein, I., 1963. Stereotyped behavior and cage size. Perc. Motor Skills 16, 231-234. https://doi.org/10.2466/pms.1963.16.1.231.

Due, M., 2006. Le bien-être du cheval, Equine Welfare: Guidelines for Keeping Horses. Warendorf, Germany, pp. 1-18.

Council Directive 98/58/EC of 20 July 1998 concerning the protection of animals kept for farming purposes, Official Journal L 221, pp 0023 - 0027.

Feenders, G. Bateson, M., 2012. The development of stereotypic behaviours in caged European starlings Sturnus vulagris. Dev.Psychobiol. 54, 773-784. https://doi.org/10.1002/dev.20623.

Feldman, R., Gordon, I., Schneiderman, I., Weisman, O., Zagoory-Sharon, O. 2010. Natural variations in maternal and paternal care are associated with systematic changes in oxytocin following 
Fraser, D., 1995. Sciences, values and animal welfare: exploring the inextricable connection. Anim.

577 Welfare 4, 103-117.

French Code rural et de la pêche maritime, 2019. Partie réglementaire, Livre II, Titre Iern Chapitre IV, Section 2, Article R.214-18, https://www.legifrance.gouv.fr/.

French Code du sport, 2017. Partie réglementaire, Livre III, Titre II, Chapitre II, Section 4, Paragraphe 5, Article A322-140, https://www.legifrance.gouv.fr/.

Fureix C, Menguy H, Hausberger M (2010) Partners with bad temper: reject or cure? A study of chronic pain and aggression in horses. PLoS One 5:e12434. https://doi.org/10.1371/journal.pone.0012434.

Fureix, C., Benhajali, H., Henry, S., Bruchet, A., Prunier, A., Coste, C., Hausberger, M., Palme, R., Jego, P. 2013. Plasma cortisol and faecal cortisol metabolites concentrations in stereotypic and non-stereotypic horses: do stereotypic horse scope better with poor environmental conditions? BMV Vet.Res. https://doi.org/10.1186/1746-6148-9-3.

Goodwin, D., Davidson, H., Harris, P., 2002. Foraging enrichment for stabled horses: effects on behaviour and selection. Eq. Vet. J. 34, 686-691. https://doi.org/10.2746/042516402776250450.

Gorecka-Bruzda, A., Jastrzebska, E., Muszynska, A., Jedrezejewska,E., Jaworski, Z, Jezierski, T., Murphy, J., 2013. To jump or not to jump? Strategies employed by leisure and sport horses. J. Vet. Behav. 8, 253-260. https://doi.org/10.1016/j.jveb.2012.10.003.

Greenwood, J, Moses, G., Bernardino, M., Gaesser, G., Weltmann, A., 2008. Intensity of exercise recovery, blood lactate disappearance, and subsequent swimming performance. J. Sport Sci 26, https://doi.org/10.1080/02640410701287263.

Grippo, A., Guerena, D. Huang, J., Khunar, N., Shah, M., Ughreja, R., Sue Carter, C., 2007. Social isolation induces behavioral and neuroendocrine disturbances relevant to depression in female and male prairie voles. Psychoneuroendocrinology 32, 966-980. https://doi.org/10.1016/j.psyneuen.2007.07.004. 
Hausberger, M., Gautier, E., Müller, C., Jego, P. 2007. Lower learning abilities in stereotypic horses. Appl. Anim. Behav.Sci. 299-306. https://doi.org/10.1016/j.applanim.2006.10.003.

Hausberger, M., Fureix, C., Lesimple, C., 2016. Detecting horses' sickness: in search of visible signs. Appl. Anim. Behav. Sci. 175, 41-49. https://doi.org/10.1016/j.applanim.2015.09.005.

Hausberger, M., Stomp, M., Sankey, C., Brajon, S., Lunel, C., Henry, S., 2019. Mutual interactions between cognition and welfare: The horse as an animal model. Neurosci. Biobehav. R. 107, 540-559. https://doi.org/10.1016/j.neubiorev.2019.08.022.

Heleski, C., Shelle, A., Nielsen, B., Zanella, A., 2002. Influence of housing on weanling horse behavior and subsequent welfare. Appl. Anim. Behav. Sci. 78, 291-302.

Hemmann, K., Raekallio, M., Kanerva, K., Hänninen, L., Pastell, M., Palviainen, M., Vainio, O., 2012. Circadian variation in ghrelin and certain stress hormones in crib-biting horses. Vet $\mathrm{J}$. 193, 97-102. https://doi.org/10.1016/j.tvj1.2011.09.027.

Holmes, M., French, K., Seckl, J. 1995. Modulation of serotonin and corticosteroid receptor gene expression in the rat hippocampus with circadian rhythm and stress. Mol. Barin. Res. 28, 186192. https://doi.org/10.1016/0169-328X(94)00207-U.

Hungarian Legislation, Law No. XXVIII of 1998 on animal protection, 1998. Consolidated 2015. https://extwprlegs1.fao.org/docs/pdf/hun15674.pdf.

Jacobs, C., Van Den Broeck, W., Simoens, P., 2007. Neurons expressinf serotonin-1B receptor in the basolateral nuclear group of the amygdala in normally behaving and aggressive dogs. Brain Res. 1136, 102-109. https://doi.org/10.1016/j.brainres.2006.11.096.

Kalen, A., Pérez-Ferreiros, A., Barcala-Furelos, R., Fernandez-Mendez, M., Padron-Cabo, A., Prieto, J., Rios-Ave, A., Abelairas-Gomez, C., 2017. How can lifeguards recover better ? A cross-over study comparing resting, running and foam rolling. Am.J. Emerg. Med. 35, 1887-1891. https://doi.org/10.1016/j.ajem.2017.06.028.

Kiley-Worthington, M. 1976. The tail movements of ungulates, canids and felids with particular reference to their causation and function as displays. Behaviour 56, 69-114. https://doi.org/10.1163/156853976X00307. 
Lagadic, H., Faure, J.M., 1987. Preferences of domestic hens for cage size and floor type as measured by operant conditioning. Appl. Anim. Behav. Sci. 19, 147-155. https://doi.org/10.1016/01681591(87)90211-5.

Laine, A.L., Gaudin, S., Chaillou, E., Cornilleau, F., Boivin, X., Coulon, M., Nowak, R., 2016. Mother-young interaction in sheep and measurement of oxytocin release in the plasma by enzyme-linked immunosorbent assay. Renc.Rech.Ruminant 23, 279.

Lansade, L., Nowak, R., Lainé, L., Leterrier, C., Bonneau, C., Parias, C., Bertin, A., 2018. Facial expression and oxytocin as possible markers of positive emotions in horses. Scientific Reports 8:14680. https://doi.org/10.1038/s41598-018-32993-z.

Lee, J., Floyd, T., Erb, H., Houpt, K., 2011. Preference and demand for exercise in stabled horses. Appl. Anim. Behav. Sci. 130, 91-100. https://doi.org/10.1016/j.applanim.2011.01.001.

Leon, M., Rosado, B., Garcia-Belenguer, S., Chacon, G., Vellegas, A., Palacio, J., 2012. Assessment of serotonin in serum, plasma ad paletelets of aggressive dogs. J. Vet. Behave. 7, 348-352. https://doi.org/10.1016/j.jveb.2012.01.005.

Lesimple, C., Fureix, C., Menguy, H., Hausberger, M., 2010. Humans' direct actions may alter animal welfare, a study on horses (Equus caballus). PLoS ONE e10257. https://doi.org/10.1371/journal.pone.0010257.

Lesimple, C., Fureix, C., LeScolan, N., Richard-Yris, M.A., Hausberger, M., 2011. Housing conditions and breed are associated with emotionality and cognitive abilities in riding school horses. Appl. Anim. Behav. Sci. 129, 92-99. https://doi.org/10.1016/j.applanim.2010.11.005.

Lesimple, C., Poissonnet, A., Hausberger, M., 2016. How to keep your horse safe? An epidemiological study about management practices. Appl. Anim. Behav. Sci. 181, 105-114. https://doi.org/10.1016/j.applanim.2016.04.015.

Lesimple, C., Gautier, E., BenHajali, H., Rochais, C., Lunel, C., Bensaïd, S., Khalloufi,A., Henry, S., Hausberger, M., 2019. Stall architecture influences horses' behaviour and the prevalence and type of stereotypies. Appl. Anim. Behva. Sci 219, 104833. httpc://doi.org/10.1016/j.applanim.2019.104833. 
Lewis, R.S., Hurst, J.L., 2004. The assessment of bar chewing as an escape behavior in laboratory mice. Anim. Welf. 13, 19-25.

Mahone, E.M., Dana Bridges, R.N., Prahme, C., Singer, H.S., 2004. Repetitive arm and hand movements (complex motor stereotypies) in children. J. Pediatrics 145, 391-395. https://doi.org/10.1016/j.jpeds.2004.06.014.

Mason, G., 1991. Stereotypies: a critical review. Anim. Behav. 41, 1015-1037. https://doi.org/10.1016/S0003-3472(05)80640-2.

McBride, S.D., Cuddeford, D., 2001. The putative welfare-reducing effects of preventing equine stereotypic behaviour. Anim Welfare. 10, 173-189.

McGreevy, P.D., Cripps, P.J., French, N.P., Green, L.E., Nicol, C.J., 1995. Management factors associated with stereotypic and redirected behaviour in the Thoroughbred horse. Eq. Vet. J. 27, 86-91. https://doi.org/10.1111/j.2042-3306.1995.tb03041.x.

McGreevy, P., Nicol, C., 1998. Physiological and behavioral consequences associated with short-term prevention of crib-biting in horses. Physiol Behav. 65, 15-23. 10.1016/S0031-9384(98)00070-5.

Mills, D.S., 2005. Repetitive movement problems in the horse, in: Mills, D.S., McDonnell, S.M. (Eds.), The Domestic Horse. Cambridge University Press, Cambridge, pp. 212-227.

Mistui, S., Yamamoto, M., Nagasawa, M., Mogi, K., Kikusui, T., Ohtani, N., Otha, M., 2011. Urinary oxytocin as a noninvasive biomarker of positive emotion in dogs. Horm. Behav. 60, 239-243. https://doi.org/10.1016/j.yhbeh.2011.05.012.

Monedero, J., Donne, B., 2000.Effects of recovery interventions on lactate removal and subsequent performance. Int. J. Sport. Med. 21, 593-597. https://doi.org/10.1055/s-2000-8488.

Nagasawa, M., Mitsui S., En, S., Ohtani, N., Ohta, M., Skuma, Y., Onaka, T., Mogi, K., Kikusumi, T., 2015. Oxytocin-gaze positive loop and the coevolution of human-dog bonds. Science 348, 333 336. https://doi.otg/ 10.1126/science.1261022.

Neumann, I. D. 2008. Brain oxytocin: A key regulator of emotional and social behaviours in both females and males. J. Neuroendocrinol. 20, 858-865. https://doi.org/10.1111/j.13652826.2008.01726.x. 
Nicol, C., 1987. Behavioural responses of laying hens after a period of spatial restriction. Anim. Behav. 35, 1709-1719. https://doi.org/10.1016/S0003-3472(87)80063-5.

Normando, S., Meers, L., Samuels, W.E., Faustini, M., Odberg, F.O., 2011. Variables affecting the prevalence of behavioural problems in horses. Can riding style and other management factors be $\begin{array}{lllll}\text { significant? Appl. } & \text { Anim. }\end{array}$ https://doi.org/10.1016/j.applanim.2011.06.012.

Owers, R, Tabram, H., 2005. Groundbreaking new report on equine welfare in the European Union (EU). Equine Vet. Educ. 27, 281-282. https://doi.org/10.1111/eve.12380.

Parker, M., Goodwin, D., Redhead, E.S., 2008. Impaired instrumental choice in crib-biting horses (Equus caballus). Behav. Brain. Res.64, 81-90. https://doi.org/10.1016/j.bbr.2008.03.009.

Pawluski, J., Jego, P., Henry, S., Bruchet, A., Palme, R., Coste, C., Hausberger, M., 2017. Low plasma cortisol and fecal cortisol metabolite measures as indicators of compromised welfare in domestic horses (Equus caballus). PLoS ONE e0182257. https://doi.org/10.1371/journal.pone.0182257.

Polish Animal Protection Act, OJ No 111, Item 724(1997); No 106, Item 668 (1998), revised 2010. extwprlegs1.fao.org/docs/pdf/pol60123.pdf.

Polverino, C. Manciocco, A., Vital, A., Alleva, E., 2015. Stereotypic behaviours in Melopsittacus undulatus: behavioural consequences of social and spatial limitation. Appl. Anim. Behav. Sci. 165, 143-155. https://doi.org/10.1016/j.applanim.2015.02.009.

Popescu, S., Diugan, E., Spinu, M., 2014. Interrelations of good welfare indicators assessed in working horses and their relationships with the type of work. Res. Vet. Sci. 96, 404-414. https://doi.org/10.1016/j.rvsc.2013.12.014.

Popescu, S., Diugan, E., 2017. The relationship between the welfare quality and stress index in working and breeding horses. Res. Vet. Sci. 115, 442-450. https://doi.org/10.1016/j.rvsc.2017.07.028.

Quirke, T. o'Riordan, R., Zuur, A., 2012. Factors influencing the prevalence of stereotypic behaviour of captive cheetahs (Acinonyx jubatus). Appl. Anim. Behav. Sci. 142, 180-197. https://doi.org/10.1016/j.applanim.2012.09.007. 
Rochais, C., Henry, S., Fureix, C., Hausberger, M., 2016. Investigating attentional processes in depressive-like domestic horses (Equus caballus). Behav. Proc. 124, 93-96. https://doi.org/10.1016/j.beproc.2015.12.010.

Rochais, C., Henry, S., Hausberger, M., 2018. "Hay-bags" and "Slow feeders": Testing their impact on horse behaviour and welfare. Appl. Anim. Behav. Sci. 198, 52-59.

Rosado, B., Garcia-Belenguer, S., Léon, M., Chacon, G., Villegas, A., Palacio, J., 2010. Blood concentrations of serotonin, cortisol and dehydroepiandrosterone in aggressive dogs. Appl. Anim. Behav. Sci. 123, 124-130. https://doi.org/10.1016/j.applanim.2010.01.009.

Sherwin, C., 2003. The motivation of group housed laboratory mice, Mus musculus, for additional space. Anim. Behav. 67, 711-717. https://doi.org/10.1016/j.anbehav.2003.08.018.

Swiss OPAn, Ordinance on animal protection, Federal Swiss Coucil 2018. https://www.admin.ch/opc/fr/classified-compilation/20080796/index.html.

Turner, R., Altemus, M., Enos, T., Cooper, B., McGuinness, T. 1999. Preliminary research on plasma oxytocin in normal cycling women: Investigating emotion and interpersonal distress. Psychiatry 62, 97-113. https://doi.org/10.1080/00332747.1999.11024859.

Visser, E.K., Ellis, A.D., Van Reenen, C.G., 2008. The effect of two different housing conditions on the welfare of young horses stabled for the first time. Appl. Anim. Behav. Sci. 114, 521-533. https://doi.org/10.1016/j.applanim.2008.03.003.

Wallner, B., Machatschke, I., 2009. The evolution of violence in men: The function of central cholesterol and serotonin. Prog. Neuro. Psychopharmacol. Biol. Psy. 33, 391-397. https://doi.org/10.1016/j.pnpbp.2009.02.006.

Waring, G.H. 2003. Horse behavior. Second ed. Noyes Publications William Andrew publishing, Norwich, New York.

Waters, A.J., Nicol, C.J., French, N.P., 2002. Factors influencing the development of stereotypic and redirected behaviours in young horses: findings of a four year prospective epidemiological study. Aq. Vet. J. 34, 572-579. https://doi.org/10.2746/042516402776180241. 
Wiedenmayer, C., 1996. Effect of cage size on the ontogeny of stereotyped behaviour in gerbils. Appl. Anim. Behva. Sci. 47, 225-233. https://doi.org/10.1016/0168-1591(95)00652-4.

Williams, E., Stewart-Knox, B., Helander, A., McConville, C., Bradbury, I., Rowland, I., 2006. Associations between whole-blood serotonin and subjective mood in healthy male volunteers. Biol. Psychol. 71, 171-174. https://doi.org/10.1016/j.biopsycho.2005.03.002.

Würbel, H., Stauffacher, M., von Holst, D., 1996. Stereotypies in laboratory mice-Quantitative and qualitative description of the ontogeny of 'Wire-gnawing' and 'Jumping' in Zur:IC and Zur:ICR nu. Ethology 102, 371-385. https://doi.org/10.1111/j.1439-0310.1996.tb01133.x.

Würbel, H., Chapman, R., Rutland, C. 1998. Effect of feed and environmental enrichment on development os stereotypic wire-gnawing in laboratory mice. Appl. Anim. Behav. Sci. 60, 6981. https://doi.org/10.1016/S0168-1591(98)00150-6.

Young, S., 2007. How to increase serotonin in the human brain without drugs. J. Psychiatry. Neurosci. $32,394-9$.

Zak, P., Stanton, A., Ahmadi, S., 2007. Oxytocin increases generosity in humans. PLoS ONE 2(11): e1128. https://doi.org/10.1371/journal.pone.0001128.

\section{VIII- TABLES}

Table 1. Behaviours expressed and recorded during behavioural (Instantaneous Scan Sampling and all occurrence) observations in paddock. The behaviours are presented in relation to sampling method used and definitions or examples are given. *Waring 2003, **Kiley Worthington 1976, ***Mills 2005, Lesimple et al 2016.

\begin{tabular}{lll}
\hline & \multicolumn{1}{c}{ Behaviour } & \multicolumn{1}{c}{ Définition / Example } \\
\hline & Feeding & Eat straw/hay \\
& Drink & Drink \\
Rest* & The horse is still, eyes half-closed or closed, standing or lying (sternal or lateral) \\
Scan Sampling & Observation & Monitoring the environment, still, eyes open, with head and ears mobile \\
& Look* & The horse looks at a precise object or direction of the environment, ears pointed \\
& Exploratory walk & towards the stimulus, neck at or above horizontal plane. \\
& Slow walk, neck below horizontal plane, loosened tail. \\
\hline \multirow{2}{*}{ All occurrence } & Active locomotion & Active walk, trot, canter, passage \\
& Excitation behaviour & Kicking, rearing, jumping
\end{tabular}




$\begin{array}{ll}\text { Vigilance** } & \begin{array}{l}\text { Alarm posture: the horse stares at a particular point in the environment, with its } \\ \text { neck and tail high }\end{array} \\ \begin{array}{l}\text { Stereotypic } \\ \text { behaviours*** }\end{array} & \begin{array}{l}\text { Including stereotypic (weaving, cribbing, wind-sucking, pacing, headshaking) and } \\ \text { abnormal repetitive behaviours (head, tongue, lip movements, repetitive licking } \\ \text { and biting, etc). }\end{array} \\ \text { Whinnies } & \begin{array}{l}\text { Whinnies } \\ \text { Non-vocal sound produced by a forceful expulsion of air through the nostrils, } \\ \text { emitted as an expression of alarm } \\ \text { Non-vocal raspy inhalation sound often related to the exploration of a new object } \\ \text { or environment. } \\ \text { Defecation, urination, rubbing, scratching, shaking, rolling }\end{array} \\ \text { Snore* } & \end{array}$

Table 2. Prevalence of complete blood cell count parameters abnormalities in our study population before the daily paddock release period. The numbers and percentages of horses presenting abnormally high or low levels are presented for each parameter as well as the total numbers and percentages of abnormalities. Veterinary norms (mean and range) are presented in the first two columns. Only the large lymphocyte concentration was normal for all horses, while MCV and MCHC were abnormal for the whole population.

\begin{tabular}{|c|c|c|c|c|c|}
\hline \multirow[b]{2}{*}{ Blood cell count parameter } & \multicolumn{2}{|c|}{ Norms } & \multicolumn{3}{|c|}{$\%$ of horses with abnormal values of BCC } \\
\hline & $\begin{array}{l}\text { Mean } \\
\text { values }\end{array}$ & $\begin{array}{l}\text { Range } \\
\text { values }\end{array}$ & $\begin{array}{c}\text { Horses with } \\
\text { values above } \\
\text { norms } \\
\mathrm{Nb}(\%)\end{array}$ & $\begin{array}{l}\text { Horses with } \\
\text { values below } \\
\text { norms } \\
\mathrm{Nb}(\%)\end{array}$ & $\begin{array}{c}\text { Total } \\
\text { Abnormalities } \\
\mathrm{Nb}(\%)\end{array}$ \\
\hline Red blood cells $\left(10^{6} / \mathrm{mm}^{3}\right)$ & 7.9 & $7.1-8.8$ & $0 \quad(0 \%)$ & $11(45 \%)$ & $11(45 \%)$ \\
\hline Leucocytes $\left(10^{6} / \mathrm{mm}^{3}\right)$ & 8.4 & $7.1-10$ & $0 \quad(0 \%)$ & $22(91.6 \%)$ & $22(91.6 \%)$ \\
\hline Haemoglobin $(\mathrm{g} / \mathrm{dL})$ & 12.8 & $11.7-14$ & $0(0 \%)$ & $5(20.8 \%)$ & $5(20.8 \%)$ \\
\hline Hematocrit (\%) & 34.3 & $31.2-37.3$ & $1(4.2 \%)$ & $3(12.5 \%)$ & $4(16.7 \%)$ \\
\hline Neutrophils (\%) & 56.8 & $51.3-66.4$ & $4(16.7 \%)$ & $4(16.7 \%)$ & $8(33.4 \%)$ \\
\hline Eosinophils (\%) & 2.3 & $1.3-3.9$ & $\begin{array}{ll}5 & (20.8 \%)\end{array}$ & $4(16.7 \%)$ & $9(37.5 \%)$ \\
\hline Basophils (\%) & 0.4 & $0.3-0.7$ & $12(50 \%)$ & $0 \quad(0 \%)$ & $12(50 \%)$ \\
\hline Monocytes (\%) & 4.1 & $3.0-5.1$ & $1(4.2 \%)$ & $2(8.3 \%)$ & $3(12.5 \%)$ \\
\hline Large lymphocytes $(\%)$ & 0.6 & $0.3-0.9$ & $0(0 \%)$ & $0 \quad(0 \%)$ & $0(0 \%)$ \\
\hline Small lymphocytes (\%) & 32.6 & $25.6-39.4$ & $4(16.7 \%)$ & $4(16.7 \%)$ & $8 \quad(33.4 \%)$ \\
\hline Platelets $\left(10^{3} / \mathrm{mm}^{3}\right)$ & 135 & $112-159$ & $0 \quad(0 \%)$ & $20(83.3 \%)$ & $20 \quad(83.3 \%)$ \\
\hline Mean Globular Rate (pg) & 15.7 & $15.2-16.6$ & $20(83.3 \%)$ & $0 \quad(0 \%)$ & $20(83.3 \%)$ \\
\hline $\begin{array}{l}\text { Mean Corpuscular Volume } \\
\left(\mu \mathrm{m}^{3}\right)\end{array}$ & 41.1 & $38.4-42.7$ & $24(100 \%)$ & $0 \quad(0 \%)$ & $24(100 \%)$ \\
\hline $\begin{array}{l}\text { Mean Corpuscular } \\
\text { Haemoglobin Concentration }\end{array}$ & 37.9 & $36.8-39.7$ & $0 \quad(0 \%)$ & $24(100 \%)$ & $24(100 \%)$ \\
\hline
\end{tabular}


Study1: testing habituation and effects on welfare indicators in stalls during the release period

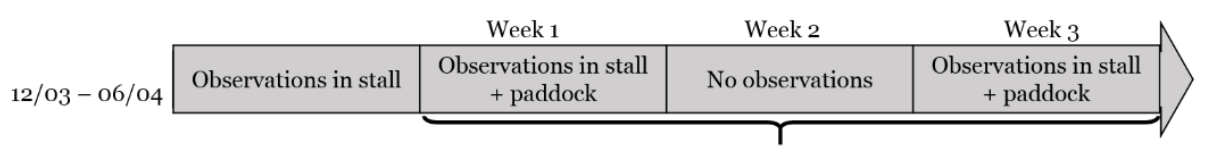

Daily paddock release

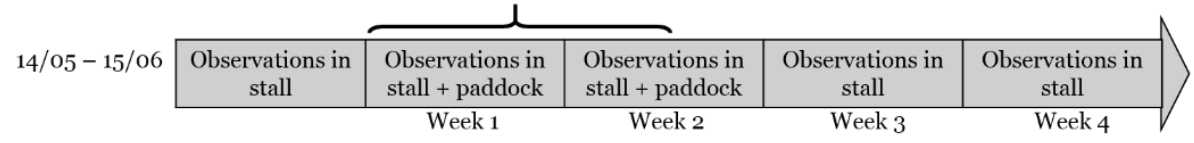

Study2: testing habituation and effects on welfare indicators after the release interruption: sustainability of the positive effects

Fig. 1. Experimental procedure and calendar for the different phases.
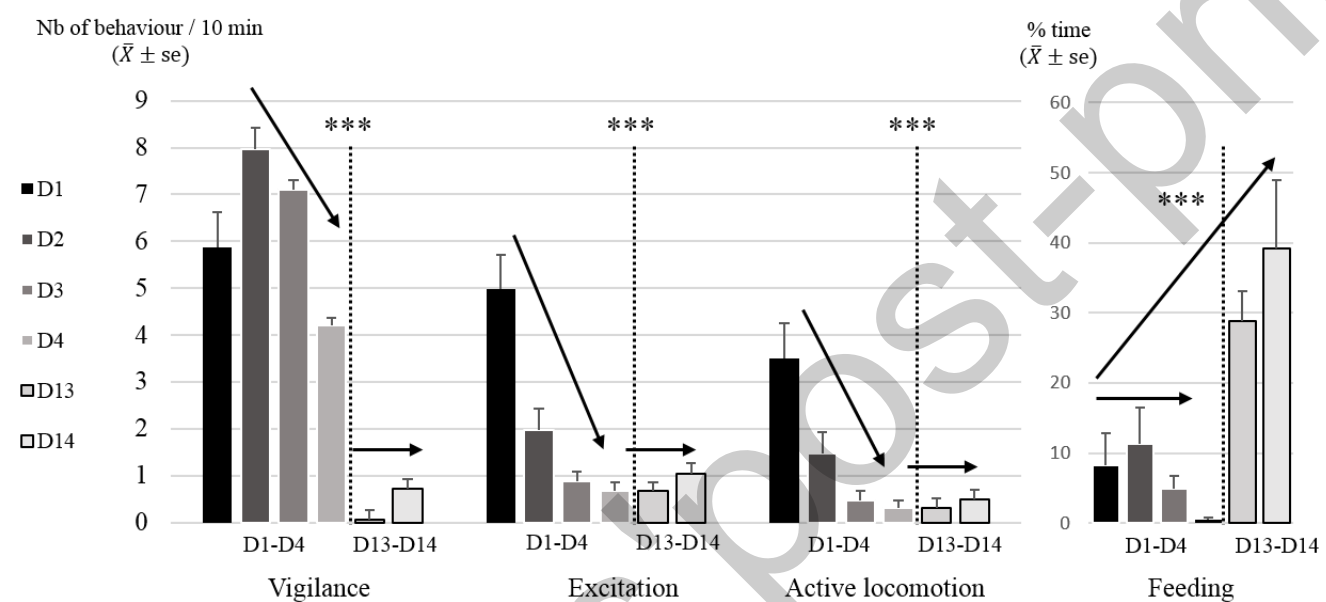

Excitation

Active locomotion

Feeding

Fig. 2 Study 1: Behavioural changes in relation to time (D1= day 1 etc. to Day14) of the 12 experimental horses while in paddock. Friedman tests, $* * * \mathrm{p}<0.001$. Vigilance, excitement and active locomotion are represented in numbers of occurrences expressed in $10 \mathrm{~min}$ (rare behaviours, ad libitum sampling). Feeding is represented in \% of time (scan sampling). The prevalence of behaviours reflecting emotional arousal (vigilance, excitement and active locomotion) decreased from D1 to D4 and remained low until D14, while feeding increased. 


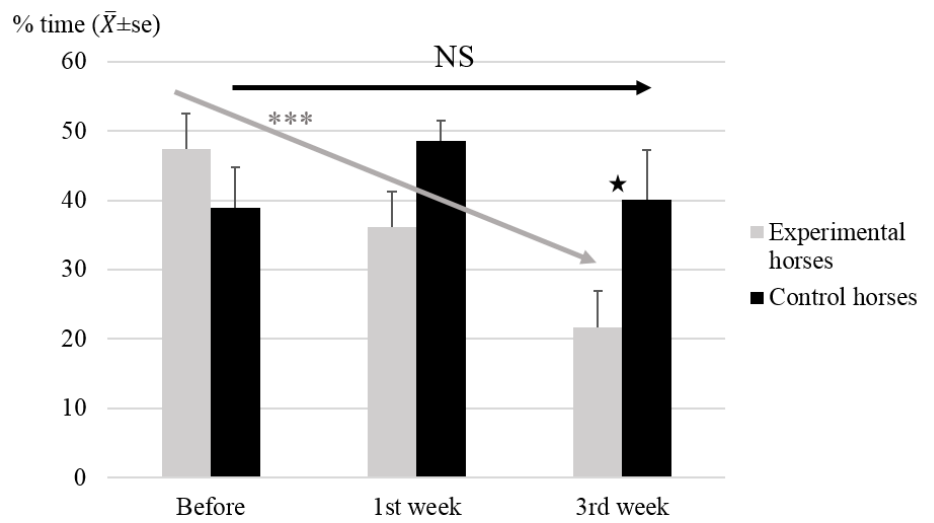

Fig. 3. Study 1: time spent with ears backwards while foraging in stalls. Friedman $(* * * p<0.001)$ and MW U

$782(\star \mathrm{p}<0.05)$ tests. Times spent with ears backwards did not differ between experimental and control groups before

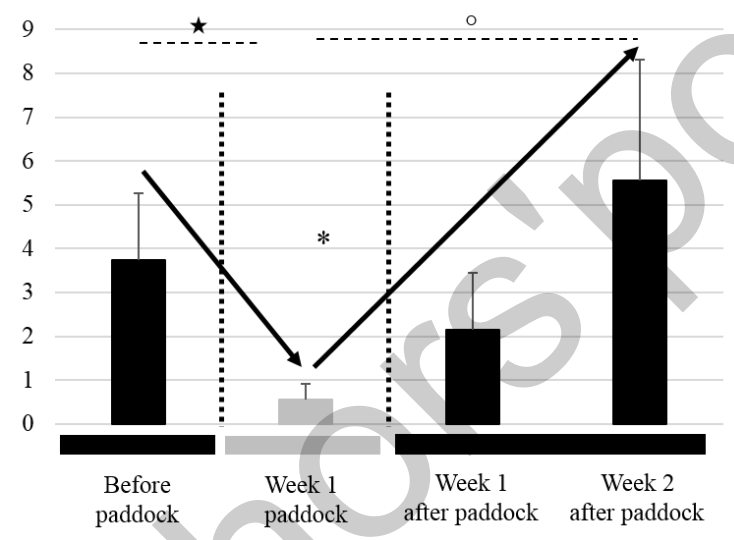

788 Wilcoxon tests, ${ }^{\star} \mathrm{p}<0.05,{ }^{\circ} \mathrm{p}<0.01$. The frequency of SB/ARB decreased significantly during the period of paddock release, increased after the paddock release period had ended and reached the SB/ARB basal level and even reached levels above that. 


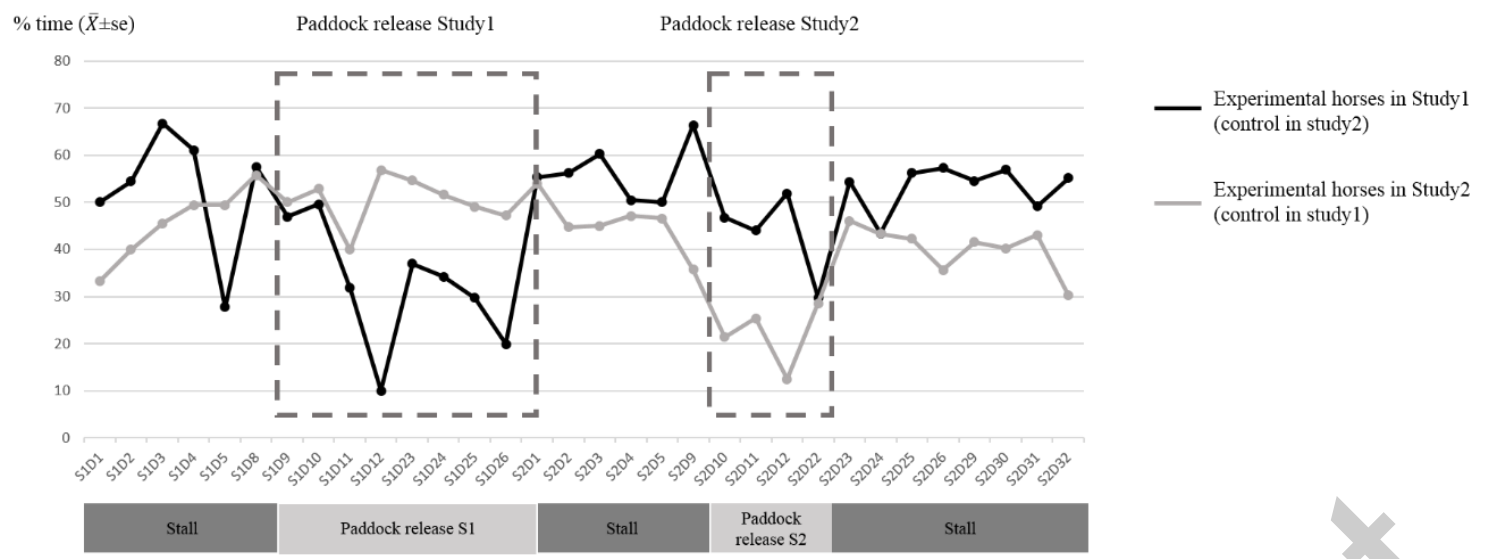

Fig. 5. Time spent with ears backwards while foraging. Variations during the experiment of time spent by

horses that switched status between study 1 and study 2 (S1D1 = Study 1-Day 1; S2D1 = Study 2-Day 1). In

black: horses that were released in a paddock during the first study; in grey: horses that were released in a paddock during the second study. In both case, the time spent with ears backwards decreased immediately at the

beginning of the paddock release period and increased instantaneously after its cessation.

Fig. 6. Oxytocin levels before and after the study 2 paddock release period, Wilcoxon test, $* p<0.05$. After the paddock release period, experimental horses (that went to paddock) presented higher oxytocin levels, while control horses' levels did not change significantly. 